\title{
INFORMACIJA
}

\section{PARLAMENTO SANTYKIS SU ARCHYVU}

\author{
DOC. DR. ANDRIUS VAIŠNYS
}

Vilniaus universiteto Komunikacijos fakultetas

Vilnius University Faculty of Communication

Sauletekio al. 9, LT-10222 Vilnius

El.paštasandrius.vaisnys@kf.vu.lt

\section{Santrauka}

Lietuvos Respublikos Seimas, kelis kartus patobulindamas valstybès archyvu statusa, tikslindamas ju funkcijas, veiklos salygas, dali dokumentu palieka už Nacionalinio dokumentu fondo ribu, nes nera nustatyta, kaip ta svarbi dalis turi patekti i parlamento archyvą. Autorius pastebi ši ypatuma, nagrinedamas Lietuvos Seimo archyvo statusa ir veiklos aplinkybes, kurios lemia parlamento struktūru santykị su dokumentu, jo saugojimu ir išliekamosios vertès kūrimu. Straipsnio tikslai - atskleisti archyvo vaidmenị dviem - istoriniu ir politinès kultūros, aspektais ir pateikti rekomendacijų, kaip būtu galima paversti parlamento archyva nacionalinès reikšmès objektu, kad Seimas Lietuvoje turètu savo tradicijos dokumentini pamata.

Reikšminiai žodžiai: archyvas; Dokumentų ir archyvų ịstatymas; istorija; parlamentinè kontrolé; Seimas.

İstatymų leidejjas, priimdamas 1995 metais Archyvų ịstatymą ir ji pataisydamas 2004, 2006 ir 2010 metais, šio įstatymo atžvilgiu nèra numatęs sau, kaip pagrindinei sprendimų prièmimo institucijai, svarbių įsipareigojimų. Šią tezę pasistengsime ne tik pagrịsti, bet ir atsakyti ị klausimą, kodèl nacionaliniam parlamentui reikètų specialaus santykio ne tik su minètu teisès aktu, bet ir tiesiogiai su Seimo archyvu. 
Pirmiausia, išsiaiškindami „Seimo archyvo“ sampratą, turime nustatyti jo santyki su dokumentu. Priminsime, jog ìstatymo str. 2.2 „archyvas“ apibrěžiamas kaip „„̦staiga ar jos struktūrinis padalinys arba kita sukauptų dokumentų saugojimo vieta“" Vieta Seimo kanceliarijoje tikrai nustatyta ir tai verta atskirai aptarti. Kita vertus, esminis žodis čia yra „dokumentas“, kurio sąvoka pasaulyje tapo diskusine dar XX a. pradžioje. Lietuvos nacionalinio parlamento atveju būtina ịvertinti jo archyvo vaidmenị ir dokumento sampratą būtent tos diskusijos kontekste ${ }^{2}$, nes dokumentui seniai priskiriama ne tik įrašyta informacija, bet ir objektai, kurie stebimi įvykyje arba išskiriami tam tikromis aplinkybėmis. Išskirtas objektas, skleidžiantis informaciją, savaime yra dokumentas, nors nebūtinai - dokumentų vadybos dalykas.

Lietuvos ịstatymų leidejjas 2004 metais apibrèžè ,dokumentą“ kaip ,juridinio ar fizinio asmens veiklos procese užfiksuotą informaciją, nepaisant jos pateikimo būdo, formos ir laikmenos “" ${ }^{\text {. }}$. Medijinis dokumento suvokimas yra dar platesnis, nes susiesime „užfiksuotą“ informaciją su jos prièmimu (su pateikimu sukuriant informacijos vartotojui reikalingas sąlygas, o informacijai - atitinkamą aplinką). Vis dèlto mums reikètų ịstatyme pateiktą apibrěžti skaityti kitaip - ne tiek „nepaisant“ būdo ir formos, kiek suvokiant ịrašytą informaciją kiekvienu prieinamu technologiniu būdu ir kiekviena forma, nes čia yra svarbus ir „daikto“, ne tik popieriaus ar elektroninès laikmenos, dokumentinis veiksnys.

Problema yra ta, kad nors, remiantis ịstatymu, Nacionalinị dokumentų fondą sudaro „valstybès ir savivaldybès institucijų, <...> veiklos dokumentai“, parlamento atveju veiklos dokumentams gana paprasta priskirti tik tuos, kurie yra registruojami nustatyta tvarka - teisès aktų projektai, taip pat Seimo

${ }^{1}$ Lietuvos Respublikos dokumentų ir archyvų įstatymas. Valstybès žinios. 1995, Nr. 1072389; aktuali redakcija, 2010.

${ }^{2}$ Buckland, M.K. What is a document. Journal of the American Society of Information Science. 1997, No. 9, p. 804-809.

${ }^{3}$ Lietuvos Respublikos dokumentų ir archyvų įstatymas, Nr. IX-2084, 2004 m. kovo 30 d. Valstybès žinios. 2004, balandžio 20, Nr. 57-1982, str. 5. 
kanceliarijos tvarkomi dokumentai ${ }^{4}$ Tačiau parlamento veikla yra platesnè nei tik įstatymų leidyba, kuri turi politinio gyvenimo kontekstą. Vertinant istatymo normas per pastaruosius 20 metu pagal tuos veiklos atvejus Seime, kai dokumentų „neliko“, matyti, jog galimybè ir tikimybė nepildyti Nacionalinio dokumentų fondo ir toliau išlieka. Tam, kad šią problemą pavyktų aptarti, pabandykime kiek plačiau pažvelgti i jos aplinkybes.

Kaip suvokiame parlamento idèją apskritai, Seimo vaidmenį valstybès kūryboje ir kaip padeda tą vaidmenį ịtvirtinti jo raiškos įrodymas - dokumentas - štai susijusių klausimų grandinè, norint suprasti, kokia Seimo archyvui skiriama vieta (taigi ir vaidmuo), ir išsiaiškinti, kokios Seimo archyvui priskiriamos funkcijos.

Parlamentą aptarnaujančios ịstaigos - Seimo kanceliarijos, struktūra atskleidžia institucinę dokumento sampratą (kaip jis pirmiausia suvokiamas istaigoje). Kadangi Archyvo skyrius yra Seimo kanceliarijos Dokumentų departamente, tai reiškia, jog dokumentas Seimo kanceliarijoje siejamas iš esmès tik su rengiamų teisès aktų (projektų) redagavimu ir kaupimu, o archyvas - su priimtų teisès aktų saugojimu. Taigi „dokumento“ judèjimas Seime aiškiai „,̧rèmintas“: jis pradeda ir baigia kūrybinį ciklą teisès akto perdavimu dviem adresais - $\mathfrak{i}$ archyvą ir publikuoti. Tuo tarpu dar 1997 metais nustatyta vadinamoji dokumentų bylų nomenklatūra ${ }^{5}$ leido matyti dokumentą kaip proceso dali (vadinas, ir politinès kūrybos proceso), tačiau susiduriame su problema, jog Seime ir Seimo kanceliarijoje apsibrèžta tik įstatymu, nutarimy ir pan. teisés aktu projektu procesu: tai atsispindi $w w w$.lrs.lt paieškos sistemoje.

Taigi formaliai „vietą“ ir jos „turinị“ galime vertinti kaip Nacionalinio

${ }^{4}$ Str. 3: „Nacionalinị dokumentų fondą sudaro valstybės ir savivaldybių institucijų, įstaigų ir ịmonių, valstybès igaliotų asmenų veiklos dokumentai, Lietuvoje įvairiais istorijos laikotarpiais veikusių valstybinių ịstaigų ir įmonių veiklos dokumentai, taip pat valstybès archyvuose saugomi dokumentai“. Lietuvos Respublikos dokumentų ir archyvų ịstatymas, Nr. IX-2084, 2004 m. kovo 30 d. Valstybès žinios. 2004, balandžio 20, Nr. 57-1982.

${ }^{5}$ Lietuvos archyvų departamento prie Lietuvos Respublikos Vyriausybès įsakymas „Dèl bendrųų dokumentų saugojimo terminų“. Valstybès žinios. 1997, rugpjūčio 22, Nr. 782006 (galiojo iki 2011 m. kovo 17 d.). Nauja Bendrujjų dokumentų saugojimo terminų rodyklès redakcija ịsigaliojo nuo $2011 \mathrm{~m}$. sausio $1 \mathrm{~d}$. 
dokumentų fondo dalį. Bet toks formalus požiūris vertintinas kritiškai, nes informacijos ir komunikacijos požiūriu archyvas turi atlikti aktyvų medijos vaidmeni, o ne būti tiesiog kaupimo vieta. Seimui šis medijinis vaidmuo sustiprintų ir institucijos raišką, jeigu dokumentas liudytų institucijos tradiciją ir atskleistu galimybes suprasti institucijos veiklą. Plati dokumento sąvokos interpretacija padètų išskleisti Seimo - valstybès kūrèjo, demokratijos garanto vaidmeni. Kodèl tai reikalinga?

Nacionaliniam tapatumui „konstruoti“. Suprantama, skaitytojas čia jau prisimins Manuelio Castellso pasiūlytą įteisinamojo tapatumo formą, kurią esą diegia dominuojanti visuomenès institucija ${ }^{6}$. Tikèkimès atverti ne tapatumo konstrukcijai reikalingą kažkokį „medžiagų sandèli“, o surinkti istorijoje išbarstytus pilietinès visuomenès daiktus ir ženklus. Šiuo aspektu vertinant, nacionalinè parlamento istorija yra Lietuvos valstybės modelio dalis. Kai šiai daliai pritrūksta pagrindimo, galime priartèti (ir priartëjame) prie lietuviams būdingų mitų teorijų, vèl užkliūdami už niekinamụjų "liberum veto“, „seimokratijos“ terminų ${ }^{7}$ ir pagiriamujų „smetonišku“ laikų (ịskaitant girą ar sviestą ${ }^{8}$ ). Šiuo atveju menkos reikšmès turi moksliniuose straipsniuose 1928-ujų Konstitucijos įvertinimas - visa imtimi ar tam tikromis dalimis - tarkime, Prezidento vieta esą iprasminta kaip Respublikos „parodija“9. Kur kas svarbesnis klausimas - kaip atrodo parlamentinès Lietuvos vizija ir kur yra jos ženklai. Taigi dominuojanti institucija privalètų pasirūpinti žymiai stipresne Lietuvos demokratijos ženklų sklaida. Nes palyginti su įstatyme pateikta apibrèžtimi, Seimo kanceliarijoje dokumentus kaupiantis archyvas turi tokią vietą, kuri menkai atskleidžia būtent medijinę „Seimo archyvo“ sampratą. Tiesiog iškelkime klausimą, ar Seimo archyvas igyja Lietuvos parlamento istorijos, demokratiją liudijančių dokumentų ir

${ }^{6}$ Castells, M. Tapatumo galia. Kaunas: Poligrafija ir informatika, 2006.

7 Römeris, M. Reprezentacija ir mandatas. Kaunas, 1927, p. 76.

8 Jeigu šiuolaikiniam vartotojui patinka tokio pavadinimo gira arba sviestas, jis neprivalo susimąstyti, jog tie produktai populiarina laikotarpị, kai buvo sulaužyta pirmoji Valstybės Konstitucija ir nuolankiai priimti net trys svetimų valstybių ultimatumai, lèmę šalies okupaciją, tačiau pasąmoningai gali suvokti, jog tai buvo ,geri laikai“‘.

9 Šidlauskas, K. Lietuvos prezidentų konstitucinès galios. Aidai. 1956, Nr. 4. 
daiktų raiškos. Šị klausimą taip pat formuluojame demokratinès valstybès kūrimo ir demokratijos sklaidos kontekste, nes kol kas dokumentas yra tik kaip istatymu leidejo produktas.

\section{1 schema}

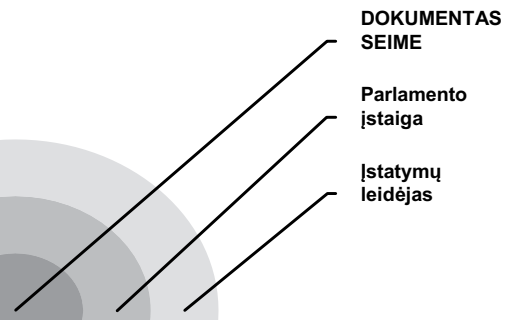

Jeigu archyvas per pastaruosius 20 metur būtų ne tik kaupęs priimamus sprendimus, bet ir (su)rinkęs dokumentuose atsispindinti ir teisès aktuc priemimo, ir politinių ìvykių (susitikimų, svarstymų, ginčų, vertinimų) procesa - t. y. politines veiklos dokumentus, taip pat ieškojęs su juo susijusių dokumentų ir juos tyręs, atsakytume ị klausimą teigiamai. Dokumento ir apskritai Seimo idejos sklaidos požiūriu priartėjame ir prie viešosios, ir prie mokslinès komunikacijos igyvendinimo, nes archyvas turètų pateikti ir tai, kas liudija Seimo idejos kilmę, tęstinumą ir valstybinį nacionalinio parlamento tapatumą.

1998 metais parengtoje Seimo ryšių su visuomene strategijoje buvo ivardytas „pagrindinis strategijos principas: Seimas yra atvira valdžios institucija “10. Toliau pabrěžiama: „Reikia siekti institucijos viešumo svarstant, skelbiant, priimant sprendimus, valdžios ir valdžių skaidrumo, institucinio bendradarbiavimo“. Viena vertus, čia turima minty pirmiausia aktualios informacijos parengimas ir sklaida ịvairioms suinteresuotoms grupèms apie ivvkkius Seime. Žinoma, tokiais atvejais politikas, informacijos rengejas, žiniasklaidos darbuotojas, auditorija nesvarsto, kaip iš vieno dokumento atsiranda dar keli ir kaip visas parlamentas virsta medija - svarbių žinių pranešèju. Kita vertus, skaidrumą ir viešumą gali pajusti tik tuomet, kai visų sprendimų dokumentai yra pasiekiami.

${ }^{10}$ Seimo ryšių su visuomene strategija 1998 m. Lietuvos Respublikos Seimo archyvas. F. 2, ap. 9 , b. 900 . 
Be to, tyrèjas-mokslininkas turètų ieškoti tos „užfiksuotos informacijos“ apie Seimą, iš Seimo, susijusios su Seimu tokiais pjūviais, kokiais visuomenè yra (buvo) šią instituciją (su)kūrusi ir kurie suteikia galimybių formuluoti ¡žvalgas. Deja, minètoje Seimo ryšių su visuomene strategijoje, vertinant situaciją 1998 m. vidaus komunikacijos aspektu Lietuvos parlamente, Seimo kanceliarijoje, parašyta ir apie archyvą: „Seimo archyvas nekaupia istorinès medžiagos (nepriskiria sau ir jam nepriskiriama tokia funkcija); nèra visu dokumentu netgi nuo 1990-03-11, taip pat svarbiu akty rengimo dokumenty, pvz., 1992 m. Konstitucijos [rengimo] darbo grupés dok [umentu]; apskritai Seimo kanceliarijoje archyvas nesuprantamas kaip svarbus padalinys" ${ }^{\text {"11. }}$.

Ši aplinkybẻ lėmė strategijos uždavinị jau prieš 12 metų rinkti ikonografinę Seimo istorijos medžiagą ir sukurti parlamento rūmų istorinio interjero koncepciją: būtent Seimo ryšių su visuomene skyrius surinko, parengė ir pateikè ją pastato interjere. Iš tikrųjų nieko tinkama, išskyrus $1990 \mathrm{~m}$. kovo 11 dienos priimtus istorinius, atspindinčius Nepriklausomybès atkūrimą ir su ja susijusius teisès aktus, nebuvo galima aptikti vadinamajame „Seimo archyve“ (t. y. Archyvo skyriuje); daugiausia medžiagos, atspindinčios parlamento istoriją nuo 1920 m., rasta Lietuvos nacionaliniame muziejuje, Lietuvos centriniame valstybès archyve, Vytauto Didžiojo karo muziejaus, kai kurių kitų muziejų fonduose, asmenų archyvuose. Taigi tik ryšių su visuomene plètojimas lèmé, jog parlamento sienos ėmè „transliuoti“ Seimo istoriją.

Vis dèlto archyvo, kaip medijos, problema yra ir aktualių îvykių šaltiniai, nes politikos procesas apskritai neịsivaizduojamas be dokumento. Istorijos, politikos, teisès mokslams ir apskritai socialiniams pokyčiams suprasti svarbu sprendimo rengimo aplinkybès. Kitaip tariant, rezultatui suvokti yra svarbūs tie komunikacijos procesą atspindintys dokumentai, kurie paaiškina, kodèl ir kaip priimtas atitinkamas teisès aktas ar kitoks sprendimas, juolab - susitarimas.

Seimo archyvo sampratos ir funkcijų trūkumus rodo kad ir reikšmingas atvejis, kai 1999 m., rengiant leidinị apie parlamento nario apkaltos istoriją ${ }^{12}$,

${ }^{11}$ Ten pat, p. 12.

${ }^{12}$ Apkaltos procedūra Seime prieš Seimo nari Audriu Butkevičiu. Vilnius: Seimo Spaudos tarnyba [i. e. Valstybės žinios], 1999 (Vilnius : Biznio mašinų komp. sp.) 107, [2] p. : iliustr. 
dokumentai (įskaitant garso ịrašus) šiai knygai buvo renkami iš įvairių institucijų, ịvairių šaltinių, ịskaitant teismo ir parlamento pareigūnus - kitaip tariant, ì parlamento archyvą visi susiję dokumentai nebuvo patekę, nors veikè speciali Seimo nutarimu sudaryta komisija ${ }^{13}$. Dokumentų rinkimas atskleidè, kad dalis jų ir būtų tikrai nepatekę i Nacionalinị dokumentų fondą, nes tarnautojai, pareigūnai dokumentų rengimo ir apdorojimo procese neturejo ịpareigojimo tarnauti istorijai. Taigi minimu atveju knygos rengejo ir leidyklos misija buvo arti tyrèjo funkcijų, nes tik rengèjas sukaupè naujausius dokumentus, išleido leidinị ir tam tikra prasme pasitarnavo politikos ir teisès mokslui. Taigi minimas leidinys tapo dokumentų byla, nes jame yra sudèti ne tik sprendimai, bet ir korespondencija.

Seimo archyvo trūkumai apima visus politinius laikotarpius nuo 1990 metų, ìskaitant 1992-ųjų Lietuvos Respublikos Konstitucijos rengimą. Kitaip tariant, archyvų specialisto - to paslapčių „vienuolio“, vaidmens parlamente teisès aktai nebuvo ir nèra išryškinę, o jis pats negalejo drịsti budèti politinių darbo grupių pasitarimuose, formalių (ypač „laikinųjų“) komisijų posėdžiuose ir juolab reikalauti iš politikų perduoti ị archyvą visą gaunamą pareigūnų korespondenciją.

Archyvo, kaip unikalios, neištrinamos dokumentų sistemos, samprata formuojasi labai lètai. Kaip parlamento narys ir parlamento ịstaigos darbuotojas regi savo darbą šioje sistemoje? Suprantama, kad parlamento įstaigos tarnautojas gali ir turi būti ịpareigotas atitinkamus dokumentus išsaugoti, tačiau politikui įteigti archyvo, kaip būtino ir patikimo dokumentų banko saugotojo vaidmeni, yra sudètingiau.

Ir tai ne tik naujausių laikų požymis.

Beveik kiekvienais metais Lietuvos žiniasklaida svarsto, kur galètų būti 1918 metais priimtas Nepriklausomybės aktas ${ }^{14}$. Gaila, bet tokiose publikacijose ar reportažuose neteko skaityti profesionalaus komentaro apie tai,

${ }^{13}$ Lietuvos Respublikos Seimo nutarimas dèl laikinosios tyrimo komisijos sudarymo, 1997 m. rugpjūčio 18 d., Nr. VIII-408 ir Lietuvos Respublikos Seimo nutarimas dèl laikinosios komisijos sudarymo, 1997 m. spalio 21 d., Nr.VIII-475.

${ }^{14}$ Pavyzdžiui: Viltis rasti Vasario 16-osios akto originalą vis labiau blèsta. Lrytas.lt. 2006, vasario 13 . 
kodèl tas aktas nebuvo užfiksuotas Lietuvos archyvuose. Stiprèja įspūdis, jog Aktas tarsi neturèjęs aprašymo, taigi saugotas nemokšiškai. Tai galima sieti su rengtais, tačiau nepriimtais Archyvų įstatymo projektais, bet problemos esmè atsiskleidžia politinès kovos ir galios aspektu: antai dar svarbesnis dokumentas pagal jo turinị ir esmę yra 1920 metų gegužès 15 dienos Steigiamojo Seimo nutarimas, kuriuo Lietuva yra skelbiama Respublika (Vasario 16-osios Aktas, atsižvelgiant ị jo turini, anuo laikotarpiu buvo tarpinis dokumentas), tačiau nèra nei Respublikos paskelbimo originalo, nei apskritai vèliau rinktų parlamentų archyvo, nes $1927 \mathrm{~m}$. balandžio mèn. paleidęs Seimą - galima taip vaizdžiai pasakyti - Prezidentas pasièmè parlamento archyvo raktus. Ir tada autoritarinis režimas net Respublikos šventę nubraukè: kasmet būdavo publikuojamas tik Vasario 16-osios dokumentas, nors iki šiol neaišku, iš kur spaustuvės gaudavo originalą, kurio dabar neturime. O visuotiniu balsavimu pirmą kartą išrinkto parlamento pirmas ir svarbiausias valstybei dokumentas - deklaracija apie Nepriklausomą ir demokratinę Respubliką iš karto liko... kažkur „palaidotas“. Akimirksniu grižtame prie M. Castellso, nes tokią situaciją jis yra apibrèžęs kaip „kuriamajj tapatumą“ ir paaiškinęs, jog tai „yra kitokio gyvenimo projektas, kuris galbūt yra kuriamas engiamo tapatumo forma, tačiau orientuojamas ị visuomenès, kaip šio

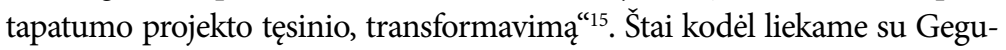
žès 15-osios dokumento, platinto atsišaukimais, kopija.

Požiūris ị archyvą tik kaip ị politinio ịvaizdžio formavimo priemonę yra suprantamas, nors, žinoma, nepriimtinas. Ką daryti, kad politikas matytų su jo veikla susijusį archyvą ne vien kaip jo įvaizdžio priemonę, bet kaip valstybinio darbo pagalbininką? Pabandykime atsakyti i šs k̇ klausimą.

Lietuvos Respublikos Seimo archyvui (t. y. Kanceliarijos skyriui) tik per pastaruosius metus sukurtos patenkinamos dokumentų saugojimo ir interesantų darbo sąlygos, nes suteiktos naujos patalpos ir reikalinga įranga. Daugėja priimamų dokumentų, susijusių su ịvykių atspindèjimu: 2010 metais priimtos 3187 „nuolatinio, ilgo ir laikino saugojimo“ bylos, per 13

${ }^{15}$ Castells, M. Tapatumo galia. Kaunas: Poligrafija ir informatika, 2006, p. 26. 
tūkstančių skaitmeninių fotografijų ${ }^{16}$, per 300 skaitmeninių vaizdo ir garso įrašų laikmenų ${ }^{17}$. Šis kaupimo procesas natūralus, bet jis būtinai reikalingas tyrimų ir mokslinio dokumentų ịvertinimo.

Paminètame Seimo ryšiu su visuomene strategijos dokumente taip pat buvo įrašyta: „Siūlyti Seimo valdybai pertvarkyti Seimo kanceliarijos archyvą (pavadinant Seimo archyvu), suteikiant daugiau funkcijų, kaip antai ieškoti, ł̇gyti ir kaupti su Seimo institucija susijusią medžiagą (dokumentus, daiktus) <...>"18. Tokị ịrašą ir suponavo pirmas argumentas demokratinès valstybės pamatams išryškinti, nes Seimo archyvo plètra padètų sustiprinti istorinę savimonę, nes jo, kaip medijos, veiksnys būtų siejamas su Lietuvos parlamento institucijos veikla nuo Lietuvos Didžiosios Kunigaikštystès. Atitinkamų parlamento istorijos dokumentų (įskaitant daiktus) ieška ir saugojimas pagrịstų politinị lituanistinio paveldo pamatą ${ }^{19}$.

Šiandien su Seimo istorija susijusių dokumentų yra įvairiuose valstybès archyvų fonduose - asmenų, institucijų, ìstaigų bylose. Neabejotinai jų yra ir kitų šalių archyvuose. Problema ta, kad parlamentas Lietuvos istorijos šaltiniuose dešimtmečių dešimtmečius buvo sumenkintas kaip mokslinio tyrimo vertas objektas (ligi mano minèto politinio „liberum veto“ asociatyvaus aspekto), todèl istorinè jo dokumento vertè dabar turètų būti atkurta. Paieškos darbas padeda tikslinti ir aprašus valstybiniuose archyvuose ${ }^{20}$. Taigi kaip tik čia specialaus - Seimo archyvo mokslininko - darbas būtų svarbus dirbant ịvairiuose fonduose Lietuvoje ir užsienyje. Paieškai ir tyrimui i ar-

${ }^{16}$ Lietuvos Respublikos Seime visi ivvykiai fotografuojami nuo $1997 \mathrm{~m}$.

${ }^{17} 2010$ metų veiklos ataskaita. Lietuvos Respublikos Seimo kanceliarijos Dokumentų departamento Archyvo skyrius. $2011 \mathrm{~m}$. vasario $15 \mathrm{~d}$.

${ }^{18}$ Min. dok., p. 12.

${ }^{19}$ Šis teiginys daikto (kaip dokumento) aspektu gali būti, laikantis dabartinių teisès aktų raidès, archyvų specialisto sukritikuotas. Tačiau išlieka vertingų dalykų išsaugojimo problema, jeigu įstatymo raidès žiūrèsime formaliai. Pavyzdžiui, 2000 m., surinkus dalị 1992 metų Konstitucijos rengimo darbo grupès užrašų iš asmeninio archyvo, atlikus kopijas, buvo galima tai pateikti Seimo archyvui. Tuo tarpu rašiklis, kuriuo buvo pasirašyta Konstitucija, lieka įrèmintas ekspozicijoje kaip neaprašytas (nedeponuotas) daiktas.

${ }^{20}$ Pavyzdžiui, 1921 metų nuotraukoje Aleksandrą Stulginskį viename archyve randi nurodytą kaip Prezidentą, nors iš tikrujų tuo metu jis buvo parlamento vadovas. Dèl tokio aprašo atsiranda klaidingas parašas parodoje, netrukus - ir knygoje. 
chyvą derètų ịleisti mokslininką kaip nuolatinį darbuotoją. Ne tik istorinių dokumentų ieška ir pateikimas reikalauja dokumentų sistemos išmanymo, bet ir kito gebejjimo - nustatyti reikalavimus, kuriais vadovaujantis dokumentas būtų îvertintas kaip susijęs su Seimu, su parlamentu. Vidutiniškai 3-4 mokslininkai, apsilankantys Seimo archyve per metus, ieško tik jų tyrimams svarbių faktų. Tačiau pats archyvas galètų užsiimti valstybės parlamento istorijai svarbių dokumentų, daiktų paieška ir tyrimu (būtų reikalinga sukurti specialų aprašą, kuriuose archyvuose saugoma su Seimu susijusių dokumentų). Būtų racionalu parlamentarizmo istorijos tyrimus matyti Seimo archyvo struktūroje. Seimo archyvo, kaip atskiros struktūros, ịkūrimas sustiprintų mokslinị darbą su dokumentais, jų paieška, tyrimais. Tam reikètų planuoti lèšas Seimo kanceliarijos metų biudžete.

Iš Seimo kanceliarijos struktūros matyti atotrūkis tarp dokumento ir parlamento istorijos. Antai Parlamentarizmo istorijos ir atminimo įamžinimo skyrius yra Komunikacijos departamente, o Archyvo skyrius - Dokumentu departamente. Seimo archyvas nėra savarankiškas padalinys. Tai rodo ne tik institucinę dokumento sampratą, apie kurią pradžioje kalbėjome. Struktūra taip pat rodo, jog archyvas dabar yra atskirtas nuo istorijos sąvokos. Tas, kuris sumanè, jog istorija gali būti atskirta nuo archyvo, tikriausiai turèjo galvoti tik apie viešąsias akcijas - parodas ir minejjimus ${ }^{21}$.

Antras argumentas sietinas su institucijos prestižu, nes kiekvieno subjekto reputaciją lemia ne tik aktualūs, bet ir kilmès dokumentai. Lietuvos parlamentarizmas turi tokią gilią tradiciją, jog ją būtina atskleisti. Prestižą lemia ir galimybè ịsitikinti institucijos darbo efektyvumu.

Šiuo atveju noriu pabrěžti, jog svarbu suvokti, kokị vaidmenį atlieka archyvas ne tik istorijai tirti, bet ir konkrečiai politikos, kultūros, ekonomikos problemai, temai, klausimui svarstyti. Priešingai nei autokratijai, demokratijai reikia dokumentinio pamato. Šio pamato funkciją gali atlikti archyvas, kai jis parodo, kad visuomené tikrai dalyvauja rinkimo ir valdymo procesuose.

${ }^{21}$ Galbūt todèl Lietuvos Seimas dažnokai primena parodų rūmus. Tačiau politinio dokumento sklaidos požiūriu tai nėra reikšminga: Seimo lankytojas turi matyti tai, kas sudaro Seimo tradicijos, parlamentinio darbo, demokratijos idèjos esmę. 


\section{Būtent archyvas gali atskleisti, kokio efektyvumo turi parlamentinė kon-} trolè. Suprantama, parlamentinè kontrolè turi daug aspektų - nuo parlamento ir vyriausybès santykių iki žiniasklaidos gebejimų pateikti politines aktualijas. Tačiau šiuo atveju pažvelkime tik archyvo - ypač skaitmeninio archyvo - galimybių aspektu. Galime suvokti archyvą dvejopai - 1) ieškantị, kaupiantị, saugantị ir tiriantị dokumentus; 2) padedantị matyti ịvykius, sprendimų eigą, raidą ir efektyvumą pasinaudojant šiuolaikinėmis technologijomis. Būtent tam, kad parlamentinè kontrolè būtų sisteminis informacijos objektas, archyvas turi igyti teisę kurti atitinkamą informavimo sistemą, kuri būtų pasiekiama virtualiam Seimo archyvo duomenų lankytojui.

\section{2 schema}

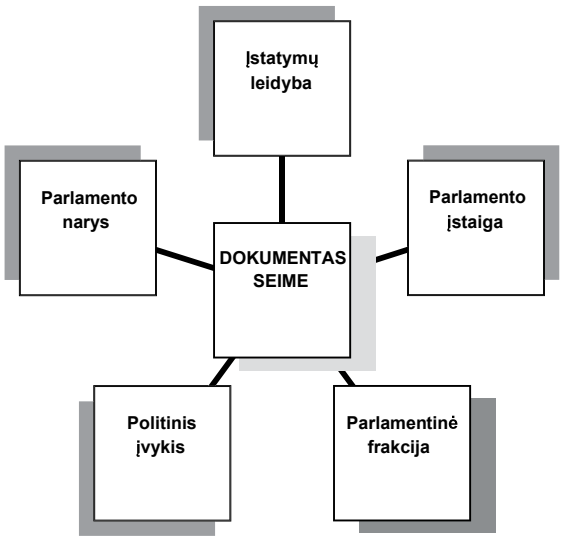

Tyrejui imponuoja, jog jis gali rasti Jungtinès Karalystès Bendruomenių rūmų narių klausimus ir atsakymus, pasirinkdamas paieškos sistemoje temą - dabar ar iš XX a. Tai jau sudaro galimybę, naudojantis šiuolaikinemis technologijomis, nustatyti ne tik parlamentinès kontrolès istoriją, bet ir efektyvumą.

Atsižvelgiant, jog Lietuvoje iš tikrųų esminiai įvykiai vyksta parlamento rūmuose, archyvo specialistui reikia suteikti daugiau galiu, kad jis galètų, vaizdžiai tariant, atsirinkti ir surinkti ịvykius ị bylas. Pavyzdžiui, naujausioje Lietuvos istorijoje, per pastaruosius 10 metų, yra pasirašyti keli „Nacionaliniai susitarimai“. Kaip palyginti šiuos dokumentus eiliniam visuomenès nariui, kur jie mums yra prieinami skaitmeninèje erdveje?

Trečias argumentas - jau ryšių su visuomene ir socialinio pasitikejjimo kontekste: archyvo, kaip medijos, vaidmuo atsiskleidžia, kai nustatomas žmogaus santykis su dokumentu. Dokumentas liudija sprendimo reikšmę. Kai vienoje dèžèje atsiduria skirtingos reikšmès ir turinio dokumentai, ne- 
bežinome, kas yra tyrimo ir saugojimo objektas. Taigi ir Seimo kanceliarija turètų aiškiau apsibrèžti dokumentų kaupimo lauką, nes skaitmeninimo projektas „Lietuvos valstybingumo istorinis paveldas elektronineje erdvéje“ iš esmès yra svarbus, tačiau pagal turinị nèra parlamentui būdingos tematikos projektas. Juolab kad panašūs, imtimi stambesni projektai yra vykdomi kitose institucijose. Parlamento tematika turètų būti specialiai išskirta.

Patikslinta, pabrèžta parlamento archyvo vieta jo ịstaigos struktūroje ir išplèstos parlamento archyvo funkcijos turètų lemti ir glaudesnị ryšį su politikais, ir kartu padaryti Seimą dar daugiau atvirą ir suprantamesnị visuomenei. Tai svarbu visų parlamento politinių struktūrų atžvilgiu, bet ypač - parlamentinių frakcijų. Tikriausiai tai vienas įdomiausių probleminių klausimų, nes frakcija yra tuo kūrybiška, jog ji atskirai palaiko tiesioginius ryšius su žiniasklaida, su išoriniais informacijos vartotojais. Frakcija yra uždara struktūra, palyginti su parlamento komitetais ar komisijomis, bet jos dokumentai istorijai, politikos tyrimams yra itin įdomūs ir svarbūs. Parlamentinès frakcijos archyvas gali būti tapatinamas su partijos archyvu, bet iš tikrujų tai neteisinga. Taip interpretuoti gali tik pats politikas, tačiau tai neteisinga dẻl valstybès lèšų, kurios skiriamos Seimui išlaikyti, naudojimo. Juolab kad yra frakcijų, kurios per kadenciją patiria pokyčių, rodančių organizacinị atotrūkị su partinėmis jègomis arba partijų sunykimą. Todèl parlamentinès kadencijos pabaigoje frakcijos, kaip sudètinès išrinkto parlamento struktūros, dokumentai turètų būti atiduodami parlamento archyvui. Dabar Seimo archyve per pastaruosius 20 metų valdančiosios frakcijos nèra palikusios savo dokumentų ${ }^{22}$. Čia turime bent jau taikyti reikalavimą oficialiems posèdžių protokolams (būtų galima numatyti tam tikras naudojimosi tokiais dokumentais sąlygas, kad iš karto tie frakcijų dokumentai netaptų rinkimų kovos įrankiu).

Visa tai, kas pasakyta, priklauso Vyriausiojo archyvaro kompetencijai (Str. 5.2: „Lietuvos vyriausiasis archyvaras - atskaitingas kultūros ministrui Lietuvos vyriausiojo archyvaro tarnybos vadovas: 1) dalyvauja formuojant

\footnotetext{
${ }^{22}$ Autoriaus interviu su Seimo kanceliarijos Dokumentų departamento Archyvo skyriaus vedèja Vida Kišūniene. 2011 m. rugsèjo 6 d. Asm. archyvas.
} 
valstybės politiką dokumentų ir archyvų valdymo ir naudojimo srityje ir ją

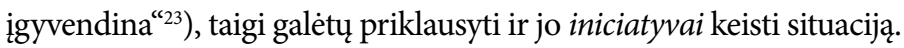

\section{Išvados ir rekomendacijos}

1. Lietuvos Seimo archyvo dokumentams prarasti XX a. 3 ir 4 dešimtmetị tiesioginès ịtakos turèjo politiniai sprendimai. Istoriniai dokumentai buvo saugomi netinkamai; jais manipuliuojant, 4 dešimtmetị buvo kryptingai naudojami politiniam ịvaizdžiui ir ideologijai kurti, skleisti bei stiprinti.

2. Būtų naudinga, jeigu Tarptautinè archyvų taryba rekomenduotų parlamentams išskirti jų archyvus kaip visiškai atskirus ir savarankiškus subjektus. Tokia rekomendacija būtų ypač tikslinga svarstyti Lietuvos ìstatymų leidejjui ir Lietuvos parlamento įstaigai - kanceliarijai. Būtų reikalinga, atkreipiant demokratijų dèmesị i politinès kultūros formavimo aspektą, rekomenduoti, kad visų parlamentinių struktūrų (taip pat ir frakcijų) dokumentai atsirastų parlamento archyve baigiant parlamento kadenciją.

3. Rekomenduoti Seimui ịkurti Seimo archyvą vietoj Seimo kanceliarijos Archyvo skyriaus ir priskirti Seimo archyvui dokumento ieškos, igijimo, kaupimo, tvarkymo ir tyrimo funkcijas. Tai galètų būti sprendžiama pasirenkant vieną modelį:

3.1. „Seimo archyvas“ Lietuvos Respublikos Seimo kanceliarijos struktūroje;

3.2. „Seimo archyvas“ kaip Lietuvos centrinio valstybès archyvo struktūrinè dalis;

3.3. Lietuvos Respublikos Seimo archyvas kaip savarankiška ịstaiga.

Formalus vertinimas, jog pagal galiojančią tvarką esą visi parlamente parengti dokumentai patenka ị Nacionalinị dokumentų fondą, yra klaidingas.

${ }^{23}$ Lietuvos Respublikos dokumentų ir archyvų ịstatymo 1, 2, 4, 5, 6, 7, 8, 11, 12, 13, 14, 15, 16, 18 straipsnių, antrojo straipsnio pavadinimo pakeitimo, 9 straipsnio pripažinimo netekusiu galios ir ịstatymo priedo papildymo ịstatymas, Nr. XI-917, $2010 \mathrm{~m}$. birželio $18 \mathrm{~d}$. Valstybès žinios. 2010, liepos 3, Nr. 79-4055. 
4. Rekomenduoti numatyti Lietuvos parlamento kanceliarijos biudžete lèšų archyvinių dokumentų paieškai ir dokumentinių vertybių įsigijimui.

5. Istorinių valstybès parlamento dokumentų kaupimas galètų būti reikšmingas Kultūros ministerijos uždavinys, igyvendinant Lietuvos Respublikos archyvų ir dokumentų ịstatymą.

6. Rekomenduoti i̊statymų leidejui pataisyti Archyvų ir dokumentų ìstatymą, kuriuo politikai, užimantys iš valstybès biudžeto apmokamas pareigas, būtų ịpareigoti formalizuoti savo santykius su valstybès archyvu, kad visi veiklos dokumentai, atspindintys politinius procesus ir ịvykius Seime, pakliūtų ị Nacionalinį dokumentų fondą. Šią problemą būtų prasminga pirmiausia svarstyti Seimo Švietimo, mokslo ir kultūros komitete.

\section{Šaltiniai}

1. Buckland, M.K. What is a document. Journal of the American Society of Information Science. 1997, No. 9, p. 804-809.

2. Castells, M. Tapatumo galia. Kaunas: Poligrafija ir informatika, 2006.

3. Lietuvos valdžia: atvirumo link? Versus aureus. 2009.

4. Šidlauskas, K. Lietuvos prezidentų konstitucinės galios. Aidai. 1956, Nr. 4.

\section{SEIMAS' RELATIONS WITH PARLIAMENTARY ARCHIVE}

\section{ANDRIUS VAIŠNYS}

\section{Summary}

Keywords: archive; the Law on Archives and Documents; history; parliamentary scrutiny; Seimas.

The aim of the article is to answer the question how the parliamentary archive could and should reveal the function of document dissemination.

The Seimas Public Relations Strategy developed in 1998 names "the key principle of the strategy: the Seimas is an open institution of public authority". It further 
emphasises that "we need to seek publicity of the institution in deliberating, declaring and passing decisions, transparency of the authority and the authorities, as well as interinstitutional cooperation".

On the one hand, this primarily implies the preparation of relevant information on events in the Seimas and dissemination thereof to various concerned groups. Certainly, in these cases a politician, an information drafter, a media representative or the audience do not consider how a number of documents originate from one document and how the entire Parliament becomes the media, i.e. the communicator of relevant news.

On the other hand, when presenting the overview of the situation in 1998 from the internal communication aspect in the Seimas, the Office of the Seimas, the above referred strategy also writes about the archive, quote: "The Seimas Archive does not store historical material (does not assign and is not assigned this function); there are not all documents even since 11.03.1990, as well as important act drafting documents, e.g. the doc[uments] of the working group on [drafting of] the 1992 Constitution; generally, the archive is not considered to be an important unit in the Office of the Seimas".

The concept of the archive as the unique, indelible system of documents has been developing very slowly. How do a parliamentarian and a servant of a parliamentary institution see their work in this system? Naturally, a servant of a parliamentary institution might and should be obliged to preserve appropriate docu- ments, yet it is much more difficult to inculcate on a politician the role of an archive as a necessary and reliable keeper of the document bank.

An archive can carry out this function of the basis, when it evidences that society is actually participating in the processes of election and governance. Namely an archive can reveal the efficiency of parliamentary scrutiny.

It would be useful if the International Council on Archives recommends to the parliaments distinguishing their archives as completely separate and autonomous subjects. This recommendation is particularly advisable to be deliberated by the Lithuanian legislative and the Lithuanian Parliament. It would be necessary to recommend, while attracting the attention of democracies to the aspect of the formation of political culture, that the documents of all parliamentary structures (including parliamentary factions) are stored in the parliamentary archive upon closing of the term of office. The author would like to recommend to the Seimas establishing the Seimas Archive instead of the Archive Unit so that the Seimas Archive is assigned the functions of document search, acquisition, storage and research and to recommend envisaging funds in the budget of the Office of the Lithuanian Parliament for the search and acquisition of archival documents. Of course, to recommend amending the Law on Archives and Documents by stipulating an obligation to the politicians holding the posts paid from the state budget to formalise their relationship with the state archive.

Iteikta $2011 \mathrm{~m}$. spalio $11 \mathrm{~d}$. 